\title{
Zhengzhou Distribution Research and Countermeasures
}

\author{
Wujun Cao* and Lulu Wan \\ Management and engineering Department, Zhengzhou University, Henan province, China
}

\begin{abstract}
With the acceleration of urbanization process in China, the city has become an increasingly important part of the logistics. This paper analyzes the current development in Zhengzhou logistics and distribution, and use the SWOT analysis model to analyze the Zhengzhou logistics and distribution strengths, weaknesses, opportunities and challenges presented in Zhengzhou distribution tertiary network architecture, and finally summarized the Zhengzhou logistics countermeasures and suggestions distribution.
\end{abstract}

Keywords. Zhengzhou; Urban logistics; Distribution

\section{Introduction}

With the increasing number of urban population and vehicles, the status of urban logistics becomes more and more important. City logistics is the logistics for the city, it serves the needs of urban development, refers to the physical flow of goods within the city, the city and the external area of goods distribution and urban waste clean-up process, and there are different models,systems and existence form, and other forms of logistics have some differences. Urban logistics is part of the logistics activities of the whole society, it is an important part of the modern logistics service system of the city, and it is the key to supply the goods or goods or services to the customers in time. However, with the increase of urban population, Urban logistics and distribution has become increasingly difficult, urban logistics distribution problems need to be resolved.

Urban logistics has many characteristics such as large amount of information, frequent logistics activities, short transportation distance, many logistics nodes, small quantity of delivery, high variety, high frequency, many factors of urban planning and control, and uneven distribution of logistics facilities, especially the current situation of logistics in our country, urban logistics started late, faster than the other services of form a complete set of urbanization process. However, with the development of urban economy, new demands and challenges have been put forward in China's urban logistics. As China has long attached great importance to the production process and neglected the circulation of the logistics, appeared in the circulation attaches great importance to the flow phenomenon of light logistics, resulting in China's logistics, especially urban logistics lack of coordination, and now the city logistics has become a huge obstacle to improve the social and economic benefits, which restricts the development of regional economy.There are some problems in China's urban logistics:

-urban transportation infrastructure is backward, the ability of transport and freight volume is limited, a serious impact on the efficiency of logistics. At the same time, because of the existence of the roundabout logistics and the backward, cross flow, the circulation link has been increased, and the cost of logistics has been increased;

-due to the lack of unified and effective management of urban logistics, repeated transport, one-way traffic and other traffic congestion caused the phenomenon of heavy traffic, and also has a huge impact on society;

-The continuous process of logistics is divided into different parts, and these belong to different departments, seriously affecting the city logistics rationalization, efficiency, etc.

This paper will take Zhengzhou as an example, analyzes the domestic and foreign research status of city logistics, through the analysis of the status of city logistics distribution in Zhengzhou, using the SWOT analysis to clear the advantages, opportunities, threats and challenges of city logistics distribution in Zhengzhou, and puts forward the corresponding countermeasures.

\section{Status and Characteristics of Logistics in Zhengzhou}

\subsection{The total economy of Zhengzhou has increased year by year, and the new requirement of logistics capability has been put forward.}

Between 2005 and 2015, GDP and the growth rate of Zhengzhou. Specific as shown in Table 1. Although Zhengzhou GDP has increased year by year, the growth rate has decreased year by year, it is related to the economic situation, but it is also related to the high cost of social logistics industry. 
Table 1. Zhengzhou GDP and growth rate

Source: Henan statistical yearbook

\begin{tabular}{|c|c|c|}
\hline Year & GDP(Billion) & $\begin{array}{c}\text { Growth } \\
\text { rate(\%) }\end{array}$ \\
\hline 2008 & 3004 & 12.2 \\
\hline 2009 & 3300 & 12 \\
\hline 2010 & 4040 & 13 \\
\hline 2011 & 4912 & 13.2 \\
\hline 2012 & 5547 & 12 \\
\hline 2013 & 6202 & 12.1 \\
\hline 2014 & 6800 & 9.3 \\
\hline 2015 & 7315 & 10.1 \\
\hline
\end{tabular}

\subsection{Types of distribution of goods and freight volume}

City logistics distribution is given priority to with consumer products related to people's daily life, according to the statistics of Zhengzhou Bureau of statistics, social consumer goods can be divided into food, drink, smoke wine, clothing, shoes and hats, knitwear, gold and silver jewelry, class, furniture, etc. At this stage, Zhengzhou has not yet built a sound statistical system of urban logistics and distribution of cargo volume, statistical methods and different caliber, can not get the freight volume data of the logistics industry in Zhengzhou . But commodity circulation and logistics has a close link, the data is easy to get on sales of goods, we use the total amount of social consumer goods data to estimate the distribution of Zhengzhou, the results of the data, as shown in Table 2.

Table 2. Zhengzhou distribution of all kinds of goods information in 2015

\begin{tabular}{|c|c|c|c|c|}
\hline Product category & $\begin{array}{c}\text { The relationship } \\
\text { between the } \\
\text { volume factor and } \\
\text { commodity } \\
\text { value(million per } \\
\text { ton) }\end{array}$ & $\begin{array}{c}\text { Commodity city } \\
\text { logistics } \\
\text { distribution } \\
\text { freight } \\
\text { volume(Million } \\
\text { tons) }\end{array}$ & $\begin{array}{c}\text { Accounted for the } \\
\text { proportion of urban } \\
\text { logistics freight } \\
\text { (\%) }\end{array}$ \\
\hline $\begin{array}{c}\text { Food, beverage, tobacco and } \\
\text { alcohol category }\end{array}$ & 159.6 & 1.63 & 97.91 & 2.363 \\
\hline $\begin{array}{c}\text { Clothing, shoes and hats, } \\
\text { knitwear category }\end{array}$ & 142.6 & 2.75 & 51.85 & 1.251 \\
\hline Gold and silver jewelry category & 39.8 & 46.62 & 0.85 & 0.021 \\
\hline Commodity category & 62.8 & 1.76 & 35.68 & 0.861 \\
\hline $\begin{array}{c}\text { Hardware, electrical equipment } \\
\text { category }\end{array}$ & 14.4 & 1.17 & 12.31 & 0.297 \\
\hline Furniture & 11.4 & 1.57 & 7.26 & 0.175 \\
\hline Petroleum and related products & 136.4 & 0.54 & 252.59 & 6.095 \\
\hline Automotive & 702.6 & 2.85 & 246.53 & 5.948 \\
\hline Coal and products & 10.1 & 0.09 & 112.22 & 2.708 \\
\hline Accommodation, catering and & 461.6 & 0.14 & 3297.14 & 79.557 \\
\hline related services & 32.1 & 1.07 & 30.00 & 0.724 \\
\hline
\end{tabular}

Source: bureau of Zhengzhou city

\subsection{Compared with the surrounding cities, some of the logistics industry's poor development in Zhengzhou}

Although in recent years, Zhengzhou logistics volume index has grown steadily, but compared to cities like Wuhan,Jinan,Xi 'an, there is a larger gap. Table 3 for the contrast of total freight volume between Zhengzhou and its peripheral cities in 2015 . 
Table 3. The contrast of total freight volume between Zhengzhou and its peripheral cities in 2015

\begin{tabular}{|c|c|c|c|c|c|c|}
\hline & Unit & $\begin{array}{l}\text { The rank of } \\
\text { Zhengzhou }\end{array}$ & Zhengzhou & Xi 'an & Wuhan & Jinan \\
\hline $\begin{array}{l}\text { Freight } \\
\text { volume }\end{array}$ & Million tons & 4 & 29367 & 50119 & 44529 & 36617 \\
\hline Highway & Million tons & 2 & 26202 & 49243 & 25023 & 17570 \\
\hline Railway & Million tons & 3 & 3101 & 858 & 9010 & 19043 \\
\hline $\begin{array}{c}\text { Civil } \\
\text { aviation }\end{array}$ & Million tons & 3 & 4 & 17.9 & 9.8 & 3.8 \\
\hline $\begin{array}{l}\text { Freight } \\
\text { turnover }\end{array}$ & $\begin{array}{l}\text { Billion tons } \\
\text { per } \\
\text { kilometer }\end{array}$ & 3 & 685.3 & 647.2 & 2556 & 1696.9 \\
\hline Highway & $\begin{array}{l}\text { Billion tons } \\
\text { per } \\
\text { kilometer }\end{array}$ & 2 & 467.5 & 416.9 & 468.4 & 305.8 \\
\hline Railway & $\begin{array}{l}\text { Billion tons } \\
\text { per } \\
\text { kilometer } \\
\end{array}$ & 4 & 217.2 & 229.3 & 1198.2 & 1389.1 \\
\hline $\begin{array}{c}\text { Civil } \\
\text { aviation }\end{array}$ & $\begin{array}{l}\text { Billion tons } \\
\text { per } \\
\text { kilometer }\end{array}$ & 4 & 0.6 & 1 & 1.5 & 2 \\
\hline
\end{tabular}

Source: Henan, Shanxi, Hubei, Shandong Statistical Yearbook

\subsection{Zhengzhou logistics is mainly based on the industrial logistics}

Total social logistics in Henan province to 95538.48 billion in 2015. The total amount of industrial logistics occupies $82.1 \%$ of the total amount of social logistics in Henan province(The Total Quantity and Composition of Social Logistics in Henan province in Figure 1). We can see from the chart,solve the problem of industrial logistics, build a smooth flow of regional logistics network, promote the coordinated development of regional logistics and city logistics are particularly important.

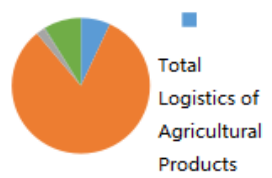

Figure 1. The Total Quantity and Composition of Social Logistics in Henan province

Source: Henan Statistical Yearbook

\subsection{The logistics industry divisions, outstanding characteristics, adjust measures to local conditions}

Zhengzhou has 1011 logistics enterprises (as of 2014), the completion of operating income of 725 billion, business tax 13.6 billion yuan, sub-sectors of view the number of units in the top three is the road transport, handling and storage industry reached $425,344,178$, these three industries accounted for $93.7 \%$ of the total number of logistics enterprises. Zhengzhou Railway Bureau in the transport industry outcrop status and the opening of the train between Zhengzhou and European, making the rail transport industry ahead of other industries.

Points in the counties, due to the unique to Erqi district railway administration support, thus Erqi district ranked first; Zhengdong New District as warehousing development is rapid, thus Zhengdong New District is in the front rank; Economic and technological development zone is to drive the development of logistics industry in Zhengzhou in recent years, Zhengzhou international land port, logistics park areas, comprehensive bonded zones and a series of industry construction growing vigorously, made economic and technological development zone logistics development prospect great. 
SWOT analysis model, also known as the situation analysis method. SWOT analysis represents the strengths, weaknesses, opportunities, and threats of an organization. This method is actually a comprehensive summary of all aspects of internal and external conditions, and analyzes the advantages and disadvantages of the organization, through the analysis of opportunities and threats, can help enterprise resources and action focused on their own projects and the place that has more opportunities.

Through the SWOT analysis we can see that the advantages of Zhengzhou logistics distribution:logistics market demand for large, commercial circulation for large. But there are obvious deficiencies, such as Industrial policy support lack of intensity, the extensive development pattern of logistics distribution, lack of competitiveness, etc. At the same time, the external opportunities are greater, national policy support, foreign capital entry, the construction of the airport port, Zhengzhou logistics distribution have played a catalytic role.In the next few years, according to the development of e-commerce, they can take the SO strategy, develop the electric business logistics and agricultural logistics, strengthen the logistics infrastructure construction, increase investment in logistics park, etc. Henan has more logistics enterprises, but they lack competitiveness, through the WO strategy to accelerate the development of logistics enterprise groups, speed up the logistics enterprise information construction, thereby improving the Zhengzhou distribution status.

Table 4. SWOT analysis on the competitiveness of Zhengzhou logistics development

\begin{tabular}{|c|c|c|}
\hline & $\begin{array}{l}\text { Strength: } \\
\text { 1. The unique geographical traffic advantages } \\
\text { 2.Good logistics infrastructure and park } \\
\text { conditions } \\
\text { 3.Huge logistics market demand space } \\
\text { 4. Active trade circulation } \\
\text { 5.Convenient customs clearance environment }\end{array}$ & $\begin{array}{l}\text { Weakness: } \\
\text { 1.Imperfect industrial policy system } \\
\text { 2.the extensive development pattern of } \\
\text { logistics distribution, lack of } \\
\text { competitiveness } \\
\text { 3.Logistics education lag, talent shortage }\end{array}$ \\
\hline $\begin{array}{l}\text { Opportunity: } \\
\text { 1.Governments at all levels } \\
\text { attach more and more } \\
\text { importance to provide } \\
\text { macro-policy support } \\
\text { 2. Strong industrial base } \\
\text { 3. Social economic sustained } \\
\text { high growth } \\
\text { 4.Opportunities for the } \\
\text { construction of the Airport } \\
\text { economic comprehensive } \\
\text { experimental area } \\
\text { 5.Infiltration of foreign } \\
\text { logistics enterprises }\end{array}$ & $\begin{array}{l}\text { SO strategy(take advantage of opportunities) } \\
\text { 1.Further promote the development of e- } \\
\text { commerce, strengthen the logistics industry } \\
\text { support } \\
\text { 2.Strengthening the connection and } \\
\text { coordination of logistics infrastructure } \\
\text { 3.Accelerate the construction of key parks }\end{array}$ & $\begin{array}{l}\text { WO strategy(take advantage of } \\
\text { opportunities to overcome weaknesses) } \\
\text { 1.Seize the opportunity and improve the } \\
\text { competitive power of logistics enterprises } \\
\text { 2.Accelerate the development of logistics } \\
\text { enterprise groups } \\
\text { 3.Accelerate the informationization process } \\
\text { of the logistics industry, change the } \\
\text { extensive development mode }\end{array}$ \\
\hline $\begin{array}{l}\text { Threat: } \\
\text { 1.Unbalanced regional } \\
\text { development } \\
\text { 2.Increased competitive } \\
\text { pressures from international } \\
\text { and domestic parties }\end{array}$ & $\begin{array}{l}\text { ST strategy (use advantage to avoid threats) } \\
\text { 1.Adjusted to local, stress the characteristic } \\
\text { 2. The implementation of "bringing in", } \\
\text { "sending out" }\end{array}$ & $\begin{array}{l}\text { WT strategy(Minimizing weaknesses and } \\
\text { avoid threats) } \\
\text { 1.Accelerate the training of logistics person } \\
\text { 2. Study advanced areas of advanced } \\
\text { experience, enhance the comprehensive } \\
\text { competitiveness }\end{array}$ \\
\hline
\end{tabular}

After the above analysis, we can see that although Zhengzhou logistics has the advantages of the policy, but there are also the following questions:

- The concept of modern logistics is lagging behind.

- Service quality and management level is relatively lacking.

- There is a lack of logistics professionals, standardized training and certification

- Scale is not high.

\section{The construction of urban logistics distribution system}

According to the above analysis, combining with some of Zhengzhou logistics policy, constructing the Zhengzhou logistics distribution system, proposing Zhengzhou to support the logistics park, the public distribution center and the end of the joint distribution, to build a three level city logistics distribution network system. Specifically to speed up the urban area of Zhengzhou and its surrounding logistics park construction, Zhengdong New District, High-Tech Zone, South Central and North Central as the base point, building four large-scale distribution center, based on common distribution in urban areas, take "logistics park - distribution center - the distribution point" of the three city distribution system. As shown in Figure 2, it is Zhengzhou logistics distribution system of the three level architecture. 


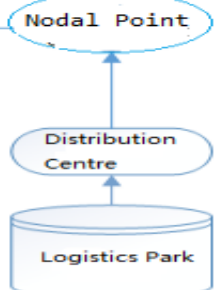

Figure 2. Zhengzhou logistics distribution system of the three level architecture

\subsection{Logistics Park}

Logistics Park is a place where logistics operations are concentrated in the area, centralizes layout of a variety of logistics facilities and different types of logistics enterprises in the space, is also a certain scale and a variety of service functions of the logistics enterprise assembly point. Zhengzhou currently has five provincial logistics parks, while Henan Bonded Logistics Center and Zhengzhou International Airport Logistics Park enter China's first demonstration logistics park. The two logistics parks have grown up in the Henan province, and have a good replication, promotion and construction of the logistics park construction and operation mode in Henan province, which has obvious promotion effect on improving the overall operation level of our logistics park.

\subsection{Distribution Center}

Distribution center is from the hands of suppliers to accept a variety of large quantities of goods, the flip, sorting, storage, circulation processing and intelligence processing and other operations, and then in accordance with the needs of many orders to prepare the goods in order to satisfactory water distribution services central flow-level distribution facilities. At present, Zhengzhou is building a city distribution center and regional distribution center. Urban distribution center is a symbol of urban modernization, because the scope of urban distribution are generally in the range of the experience of motor transport, so this distribution center can be directly delivered to the final user, and the use of motor transport for distribution. Short distance, strong ability can respond to engage in more varieties, less bulk, multiple user distribution. Regional distribution center is taking into account the distribution of the surrounding cities of Zhengzhou and other cities in the country.

\subsection{Nodal Point}

The distribution point is to undertake the distribution center, a link between customers. At present most express distribution nodal point distributes in Zhengzhou city each district, office buildings and other crowded areas. Under normal circumstances, when people have a demand, the nodal point will quickly meet people's needs and requirements.

At present, Zhengzhou has a lot of nodal point, but its security measures and the daily management of most do not meet the specification, this is also the need to further regulate the place. Distribution point can be said to be an important part of the whole logistics chain, is the most direct impact on customer satisfaction, because the distribution point is a direct contact with the customer's front.

Mature logistics distribution system have a greater role in optimizing the whole process, promoting the progress of the industry, using good social resources. The establishment of a good city logistics distribution system in Zhengzhou not only has a positive role in promoting Zhengzhou city logistics distribution, and has a great effect on the development of the urban logistics industry in other cities around the city.

\section{Countermeasures and Suggestions}

After the above analysis, it show the Zhengzhou city distribution of the status and problems, using SWOT analysis is to let us know the advantages and disadvantages of Zhengzhou logistics distribution, as well as measures to be taken in the future. This paper believes that Zhengzhou logistics can be strengthened from the following aspects of the construction, to create a suitable for Zhengzhou distribution system.

- Support the common distribution model. Common distribution has already been implemented in Japan, Germany, Singapore and other countries, and formed standardized system. The essence is to improve the efficiency through the integration of scale. Common distribution can not only reduce the owner's operating costs, but also to save resources for the community. 
Construction of urban distribution transportation channel, dedicated parking spaces. Daily necessities distribution, food distribution, distribution of other social materials need to occupy a public location, especially now the distribution frequency is more and more high, there are more and more distribution categories. Therefore it needs special distribution channel, special parking space, etc. At present Beijing, Shenzhen and other cities are set for the city's distribution of a dedicated transport channel. As a developing city, Zhengzhou needs to set up a special distribution channel for urban distribution and improve the efficiency of urban distribution.

Guide the logistics enterprises to improve the level of information technology. Although many people are engaged in urban transport and distribution of personnel in Zhengzhou, but there is no reasonable use of good social resources and advanced technology development. Establishing a public logistics platform and using internet of things, RFID and positioning and other advanced technologies can significantly improve the quality and level of service and save part of the cost for enterprises, etc.

Improve the urban distribution management system and give full play to the role of industry organizations. Distribution of the city needs a large number of enterprises to participate in.In Henan province, a large number of logistics and distribution enterprises concentrated in Zhengzhou. However, there is no industry organization in which to play a good role. So it is urgent to have a reasonable organization of the industry organization.

\section{Conclusion}

This paper first analyzes the status of Zhengzhou logistics present situation, proposing the existing problems, using the SWOT analysis method to make us more directly see the strengths weaknesses opportunities and challenges of city logistics distribution, putting forward Zhengzhou logistics distribution system architecture. In the end, it gives four countermeasures and suggestions to the urban logistics distribution in Zhengzhou. But there are some shortcomings, such as some data is not found, although this paper refers to the data using methods of some other papers, but it did not verify the rationality of these data.

\section{References}

1. Ying Li,Zhaoqiang Liu.Research on the present situation and distribution system of Guangzhou City.Highways \& Automotive Applications.J.E 2,82-87(2015).

2. Guang Hua,Na Dong. The bottleneck and countermeasure of urban distribution in China.China Logistics \& Purchasing.J.E 6,74-75(2014).

3. Lieying Luo,Zhongcheng Zheng.Study on the problems and Countermeasures of the development of city distribution logistics in Wenzhou.Business.J.E 4,240-241(2015).

4. Yuchao. Hu.Study on Establishing Urban Green Logistics and Distribution System.Logistics Technology.J.E 31, 5659(2012).

5. Guoqing Dong.Analysis on the Advantages and Disadvantages of the Third Party Logistics Enterprise Common Distribution Mode.Modern Business Trade Industry.J.E 20, D (2012).

6. Hongpeng Wang.Construction strategy and policy measures of urban logistics distribution system in Xiamen.China Logistics \& Purchasing.J.E 5, D (2010).

7. Hongpeng Wang.Con.struction strategy and policy measures of urban logistics distribution system in Xiamen.Comprehensive Transportation.J.E 5, D (2010).

8. Xiuming Niu.On the development of urban common distribution.Logistics Technology.J.E 6, D (2013). 